\title{
Haloarcula salaria sp. nov. and Haloarcula tradensis sp. nov., isolated from salt in Thai fish sauce
}

\begin{abstract}
Correspondence
Somboon Tanasupawat Somboon.T@chula.ac.th
\end{abstract}

\author{
Sirilak Namwong, ${ }^{1}$ Somboon Tanasupawat, ${ }^{2}$ Takuji Kudo ${ }^{3}$ \\ and Takashi Itoh ${ }^{3}$
}
${ }^{1}$ Department of Biotechnology, Faculty of Science and Technology, Suan Sunandha Rajabhat University, Bangkok 10300, Thailand
${ }^{2}$ Department of Biochemistry and Microbiology, Faculty of Pharmaceutical Sciences, Chulalongkorn University, Bangkok 10330, Thailand
${ }^{3}$ Japan Collection of Microorganisms, RIKEN BioResource Center, 2-1 Hirosawa, Wako-shi, Saitama 351-0198, Japan

Two red-pigmented, strictly aerobic, pleomorphic rod-shaped and extremely halophilic archaea,

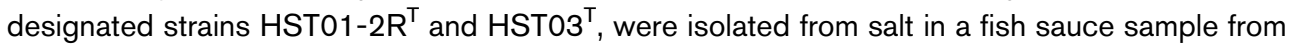
Thailand. The novel strains grew optimally at $37{ }^{\circ} \mathrm{C}, \mathrm{pH} 7.0$, and in the presence of $20-25 \%$ $(\mathrm{w} / \mathrm{v}) \mathrm{NaCl}$. The DNA G $+\mathrm{C}$ contents of the isolates were $61.6-62.2 \mathrm{~mol} \%$. Phylogenetic analysis based on a comparison of $16 \mathrm{~S}$ rRNA gene sequences revealed that strains HST01-2R ${ }^{\top}$ and HSTO3 $^{\top}$ were placed in the radiation of species of the genus Haloarcula. The chemotaxonomic properties of the two strains, i.e. the presence of MK-8 and $\mathrm{MK}-8\left(\mathrm{H}_{2}\right)$ as the major menaquinone components and $\mathrm{C}_{20} \mathrm{C}_{20}$ derivatives of phosphatidylglycerol, phosphatidylglycerol phosphate methyl ester, phosphatidylglycerol sulfate and a triglycosyl diether as major polar lipids, supported the assignment of the two strains to the genus Haloarcula. Nevertheless, several phenotypic features and the low DNA-DNA relatedness between the two strains and related species of the genus Haloarcula (13.4-46.9\%) enabled the strains to be distinguished from each other and from recognized species. Therefore, strains $\mathrm{HSTO}^{-2} \mathrm{R}^{\top}$ and $\mathrm{HST03}{ }^{\top}$ represent two novel species in the genus Haloarcula, for which the names Haloarcula salaria sp. nov. and Haloarcula tradensis sp. nov. are proposed, respectively. The type strains are HST01-2R ${ }^{\top}\left(=\mathrm{BCC} 40029^{\top}=\mathrm{JCM}\right.$ $\left.15759^{\top}=\mathrm{PCU} 313^{\top}\right)$ and $\mathrm{HSTO}^{\top}\left(=\mathrm{BCC} 40030^{\top}=\mathrm{JCM} 15760^{\top}=\mathrm{PCU} 314^{\top}\right)$.
The genus Haloarcula was firstly described by Torreblanca et al. (1986) with the type species Haloarcula vallismortis. To date, seven additional species have been described, Har. amylolytica, Har. argentinensis, Har. hispanica, Har. japonica, Har. marismortui, Har. mukohataei and Har. quadrata (Juez et al., 1986; Oren et al., 1990, 1999; Takashina et al., 1990, 1991; Ihara et al., 1997; Yang et al., 2007). Har. mukohataei has since been transferred to the genus Halomicrobium as Hmc. mukohataei (Oren et al., 2002). These extremely halophilic archaea are red-pigmented

Abbreviations: DGD, diglycosyl diether; PG, phosphatidylglycerol; PGP$\mathrm{Me}$, phosphatidylglycerol phosphate methyl ester; PGS, phosphatidylglycerol sulfate; TGD-2, triglycosyl diether.

The GenBank/EMBL/DDBJ accession numbers for the 16S rRNA gene sequences of strain HST01-2R' are FJ429317 (rrnA) and FJ429318 (rrnB) and FJ429313 (rrnA), FJ429316 (rrnB) and FJ429314 (rrnC) for strain HSTO3 $^{\top}$.

Supplementary figures are available with the online version of this paper. and short pleomorphic rods ranging from almost regular to irregular shapes. Fish sauce, which is a common fermented food in Thailand, is rich in various nutrients, particularly amino acids and peptides. It also contains a high concentration of $\mathrm{NaCl}$, thus allowing halophilic bacteria and archaea to thrive (Lopetcharat et al., 2001). Previous studies of this product have found strains of halophilic archaea, Halobacterium salinarum, Halococcus thailandensis, Hcc. saccharolyticus and Natrinema gari (Thongthai et al., 1992; Namwong et al., 2007; Tapingkae et al., 2008; Tanasupawat et al., 2008-2009), and moderately halophilic bacteria, 'Halobacillus thailandensis', Lentibacillus salicampi, L. juripiscarius, L. halophilus and Chromohalobacter salexigens (Chaiyanan et al., 1999; Namwong et al., 2005; Tanasupawat et al., 2006, 2008-2009). This paper deals with the characterization of two novel extremely halophilic archaea from the salt in a sample of fish sauce based on their phenotypic and chemotaxonomic characteristics, DNA-DNA relatedness and 16S rRNA gene sequences. 
The halophilic archaeal strains were isolated from salt from a sample of fish sauce collected in Trad province, Thailand. The collected salt was suspended in JCM medium No. 168 broth and the suspension was spread on agar plates of the same medium [composed of $\left(\mathrm{l}^{-1}\right): 200 \mathrm{~g} \mathrm{NaCl}, 5 \mathrm{~g}$ Casamino acids (Difco), $5 \mathrm{~g}$ yeast extract (Difco), $2 \mathrm{~g} \mathrm{KCl}$, $3 \mathrm{~g} \mathrm{Na}_{3} \mathrm{C}_{6} \mathrm{H}_{5} \mathrm{O}_{7}, 1 \mathrm{~g}$ glutamic acid, $20 \mathrm{~g} \mathrm{MgSO}_{4} .7 \mathrm{H}_{2} \mathrm{O}$, $0.36 \mathrm{~g} \mathrm{FeCl} .4 \mathrm{H}_{2} \mathrm{O}, 0.0036 \mathrm{~g} \mathrm{MnCl}_{2} \cdot 4 \mathrm{H}_{2} \mathrm{O}, 20 \mathrm{~g}$ agar, $\mathrm{pH}$ 7.2] and incubated at $37{ }^{\circ} \mathrm{C}$ for $1-2$ weeks. Unless otherwise stated, the strains were grown in liquid or on agar media based on JCM medium No. 168.

Phenotypic characteristics were determined in accordance with the proposed minimal standards for the description of new taxa in the order Halobacteriales (Oren et al., 1997). Cell morphology and motility were examined by phasecontrast microscopy (BX50; Olympus). Gram staining was performed as described by Dussault (1955). Colonies were observed on JCM medium No. 168 agar plates after incubation at $37{ }^{\circ} \mathrm{C}$ for 7 days. Tests for catalase and oxidase activities, nitrate reduction, methyl red/VogesProskauer reactions, the formation of indole and the hydrolysis of gelatin, skimmed milk, Tween 80 , tyrosine and xanthine were performed as described by Barrow \& Feltham (1993). Carbon utilization from carbohydrates was determined in Leifson (1963) medium. Casitone was omitted for the carbon utilization test whereas Tris/HCl was omitted for the acid production test. Anaerobic growth was observed in the standard growth medium with $0.5 \%$ nitrate using a Gaspak (BBL) anaerobic jar. Growth at various temperatures $\left(5-60{ }^{\circ} \mathrm{C}\right)$ was examined using a temperature gradient incubator (model TN-3; Advantec). The effects of initial $\mathrm{pH}(5-9)$ for growth were determined in JCM medium No. 168. The effects of $\mathrm{NaCl}$ concentration on growth were tested in a medium containing 0-30\% $(\mathrm{w} / \mathrm{v}) \mathrm{NaCl}$. At lower $\mathrm{NaCl}$ concentrations [0-2\% (w/v) $\mathrm{NaCl}, \mathrm{MgSO}_{4} \cdot 7 \mathrm{H}_{2} \mathrm{O}, \mathrm{KCl}$ and $\mathrm{Na}_{3} \mathrm{C}_{6} \mathrm{H}_{5} \mathrm{O}_{7} \cdot 2 \mathrm{H}_{2} \mathrm{O}$ were omitted from the test medium. Likewise, the requirement for $\mathrm{Mg}^{2+}$ was tested in JCM medium No. 168 by omitting $\mathrm{MgSO}_{2} \cdot 7 \mathrm{H}_{2} \mathrm{O}$ but supplementing with $2 \%(\mathrm{w} / \mathrm{v}) \mathrm{Na}_{2} \mathrm{SO}_{4}$ and $0-10 \%(\mathrm{w} / \mathrm{v}) \mathrm{MgCl}_{2}$. Growth was determined by measuring the culture turbidity at $660 \mathrm{~nm}$. The antibiotic susceptibility of the strains was tested as described by StanLotter et al. (2002).

Menaquinones were analysed by the reversed-phase HPLC method of Komagata \& Suzuki (1987) and confirmed by MS running in EI mode and using a direct insertion probe (QPMS-QP5050A; Shimadzu). Polar lipids were extracted serially by using four different solvent solutions [first extraction with methanol:0.3\% $\mathrm{NaCl}(100: 1, \mathrm{v} / \mathrm{v})$, followed by petroleum ether, chloroform : methanol: water $(90: 100: 30, \mathrm{v} / \mathrm{v})$ and finally chloroform: methanol: water $(50: 100: 40, \mathrm{v} / \mathrm{v})]$ and their extracts were separated by single dimensional silica gel TLC (Hezayen et al., 2002). Methanolysis of the polar lipids was conducted by mixing the dried cells with methanol $(3 \mathrm{ml})$, toluene $(3 \mathrm{ml})$ and concentrated $\mathrm{H}_{2} \mathrm{SO}_{4}(0.1 \mathrm{ml})$, followed by heating at $55{ }^{\circ} \mathrm{C}$ for $9 \mathrm{~h}$. Core diether moieties were extracted with hexane and the hexane extracts were developed on TLC using the procedure described by Ross et al. (1981). Two-dimensional TLC of the total polar lipids was conducted according to the method of Minnikin et al. (1984).

Genomic DNA was isolated and purified according to the method of Saito \& Miura (1963). The DNA G +C content was determined with the method of Tamaoka \& Komagata (1984) using reversed-phase HPLC. DNA-DNA hybridization was conducted as reported previously (Ezaki et al., 1989) and detected by the colorimetric method reported by Tanasupawat et al. (2000). The almost complete $16 \mathrm{~S}$ rRNA gene sequences of strains HST01-2R $\mathrm{R}^{\mathrm{T}}$ and $\mathrm{HST} 03^{\mathrm{T}}$ were PCR-amplified with primers 20F (5' ${ }^{\prime}$-TCCGGTTGATCCTGCCG, position 8-24 according to the Escherichia coli numbering system) and 1540R (5'-GGAGGTGATCCAGCCG, position 1540-1525) (Enache et al., 2007). The amplified DNA fragments were separated by agarose gel electrophoresis and recovered by using a GenElute Minus EtBr Spin Column (Sigma). PCR products were ligated into the pT7blueT-vector (Novagen) using a Takara ligation kit version 2.1 according to the manufacturer's instructions and transformed into E. coli JM 109 by the heat-shock technique (Shao et al., 2004). Plasmids were extracted with a QIAprep Spin Miniprep kit (Qiagen) using the protocol supplied by the manufacturer. Inserts were amplified using the primers T7 (5'-TAATACGACTCACT ATAGGG-3') and U19 (5'-GTTTTCCCAGTCACGACGT$3^{\prime}$ ) (Enache et al., 2007). PCR products were sequenced using a BigDye Terminator Cycle Sequencing Ready Reaction kit (version 3.0; Applied Biosystems) in the ABI PRISM 310 Genetic Analyzer (Applied Biosystems). The phylogenetic tree was constructed as described by Thompson et al. (1997), Saitou \& Nei (1987), Kumar et al. (2001) and Felsenstein (1985).

Two strains of non-motile, red-pigmented and extremely halophilic archaea were isolated from the salt in the samples of fish sauce. Colonies on JCM medium No. 168 agar plates were small $(0.8-2.3 \mathrm{~mm}$ in diameter), entire, translucent and convex. Cells from late-exponential to stationary phase cultures were pleomorphic, rod-shaped and approximately $0.6-1.2 \times 1.0-2.5 \mu \mathrm{m}$ (Fig. 1a and b) and lysed when suspended in distilled water. The strains grew at salinities of $15-30 \%(\mathrm{w} / \mathrm{v}) \mathrm{NaCl}$, showing optimal growth at $20-25 \%$ $(\mathrm{w} / \mathrm{v}) \mathrm{NaCl}$. They required at least $2 \%(\mathrm{w} / \mathrm{v}) \mathrm{Mg}^{+}$and grew

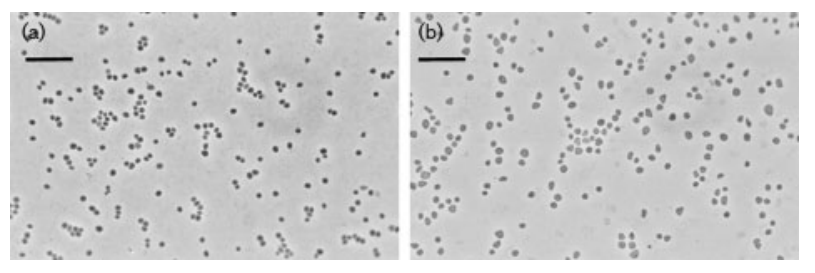

Fig. 1. Phase-contrast micrographs of cells of strains $H S T 01-2 R^{\top}$ (a) and $\mathrm{HSTO3}^{\top}$ (b) grown on JCM medium No. 168 agar plates. Bars, $10 \mu \mathrm{m}$. 
optimally when 4-6\% (w/v) $\mathrm{Mg}^{+}$was added to the medium with $20 \%(\mathrm{w} / \mathrm{v}) \mathrm{NaCl}$. The growth temperature range was $15-45{ }^{\circ} \mathrm{C}$ (optimum, $37{ }^{\circ} \mathrm{C}$ ) and the $\mathrm{pH}$ range was $6-8$ (optimum, pH 7). The physiological and biochemical properties of the novel strains are summarized in the species description and Table 1.

The chemotaxonomic features of the two strains, i.e. the presence of $\mathrm{C}_{20} \mathrm{C}_{20}$ glycerol diether derivatives of phosphatidylglycerol sulfate (PGS) and triglycosyl diether (TGD-2), and MK-8 and MK-8( $\left.\mathrm{H}_{2}\right)$ as the major menaquinone components, conformed to the previously published descriptions of the genus Haloarcula (Torreblanca et al., 1986; Juez et al., 1986; Grant \& Larsen, 1990; Oren et al., 1990, 1999, 2009; Takashina et al., 1990; Ihara et al., 1997; Yang et al., 2007). Thin layer chromatograms of the polar lipid fractions of strains HST01-2R $\mathrm{R}^{\mathrm{T}}$ and $\mathrm{HST}^{\mathrm{T}}{ }^{\mathrm{T}}$ revealed $\mathrm{C}_{20} \mathrm{C}_{20}$ glycerol diether derivatives of phosphatidylglycerol (PG), phosphatidylglycerol phosphate methyl ester (PGPMe), PGS, TGD-2, diglycosyl diether (DGD) and two unknown phospholipids (see Supplementary Fig. S1 in IJSEM Online). The TLC of the methanolysis samples from strains HST01-2R ${ }^{\mathrm{T}}$ and $\mathrm{HST}_{0} 3^{\mathrm{T}}$, as well as those from Har. amylolytica JCM $13557^{\mathrm{T}}$, Har. argentinensis $\mathrm{JCM} 9737^{\mathrm{T}}$, Har. hispanica JCM $8911^{\mathrm{T}}$ and Hcc. thailandensis JCM $13552^{\mathrm{T}}$ revealed that the two novel strains contained only $\mathrm{C}_{20} \mathrm{C}_{20}$, core lipids (see Supplementary Fig. S2). The two-dimensional TLC of the total polar lipids of strains $\mathrm{HST} 01-2 \mathrm{R}^{\mathrm{T}}$ and
$\mathrm{HST} 3^{\mathrm{T}}$ is presented in Supplementary Fig. S3. The novel strains contained MK-8 (91.8-91.9\%) and MK-8( $\left.\mathrm{H}_{2}\right)(8.2-$ $8.8 \%)$ as the menaquinone components. The genomic DNA $\mathrm{G}+\mathrm{C}$ contents of the strains were $61.6-62.2 \mathrm{~mol} \%$ (Table 2)

It has been demonstrated that the recognized members of the genus Haloarcula examined so far harbour at least two different 16S rRNA gene copies, which have been categorized into two 16S rRNA gene types (type I and II) showing $4.8-5.6 \%$ divergence from each other (Gemmell et al., 1998; Arahal et al., 1996; Ihara et al., 1997; Oren et al., 1999; Yang et al., 2007; Baliga et al., 2004; Cui et al., 2009). The two novel isolates also revealed this 16S rRNA gene polymorphism: strain HST01-2 $\mathrm{R}^{\mathrm{T}}$ contained at least two 16S rRNA gene copies, $r r n A$ (1479 bp) and $r r n B$ (1484 bp), and strain $\mathrm{HST} 03^{\mathrm{T}}$ contained three $16 \mathrm{~S}$ rRNA gene copies, $r r n A$ (1489 bp), rrnB (1487 bp) and $r r n C(1487 \mathrm{bp})$, as shown in Fig. 2. All of the 16S rRNA gene copies belonged to type II. On the phylogenetic tree (Fig. 2), the three gene copies of strain $\mathrm{HST}_{0} 3^{\mathrm{T}}$ seemed to be separated from the hitherto reported type II genes, and only one sequence from Haloarcula hispanica ATCC $33960^{\mathrm{T}}$ (GenBank accession no. U68541) was closely related to the $r r n C$ gene (97.91\% similarity). On the other hand, the $r r n A$ and $r r n B$ gene sequences of strain HST01-2R $\mathrm{R}^{\mathrm{T}}$ were included in the radiation of the type II genes. The DNA-DNA hybridization study revealed that strains HST01-2R ${ }^{\mathrm{T}}$ and $\mathrm{HST} 03^{\mathrm{T}}$ had low DNA-DNA relatedness $(<46.9 \%)$ to each other

Table 1. Differential characteristics of strains $\mathrm{HSTO}-2 \mathrm{R}^{\top}, \mathrm{HSTO}^{\top}$ and species of the genus Haloarcula

Taxa: 1, HST01-2R ${ }^{\mathrm{T}} ; 2, \operatorname{HST}^{\mathrm{T}}$; 3, H. argentinensis JCM $9737^{\mathrm{T}} ; 4$, H. amylolytica JCM $13557^{\mathrm{T}} ; 5$, H. hispanica JCM 8911 ${ }^{\mathrm{T}}$; 6, H. quadrata JCM $11048^{\mathrm{T}}:$ 7, H. vallismortis JCM $8877^{\mathrm{T}}$. +, Positive; -, negative; w, weak.

\begin{tabular}{|c|c|c|c|c|c|c|c|}
\hline Characteristic & 1 & 2 & 3 & 4 & 5 & 6 & 7 \\
\hline Cell shape & Pleomorphic & Pleomorphic & Triangular & Short rods & Short rods & Square & Rods \\
\hline \multicolumn{8}{|l|}{ Range for growth: } \\
\hline $\mathrm{MgCl}_{2}(\%, \mathrm{w} / \mathrm{v})$ & $2-10$ & $2-10$ & $2-10$ & $0-10$ & $0-10$ & $1-10$ & $1-10$ \\
\hline \multicolumn{8}{|l|}{ Hydrolysis of } \\
\hline Starch & + & $\mathrm{w}$ & $\mathrm{w}$ & + & + & - & - \\
\hline Tyrosine & - & - & - & + & + & - & - \\
\hline Nitrate reduction & - & - & - & - & - & + & + \\
\hline \multicolumn{8}{|l|}{ Acid from } \\
\hline D-Glucose & - & - & + & - & - & - & - \\
\hline D-Galactose & - & - & + & + & - & - & - \\
\hline Raffinose & + & - & - & - & - & - & - \\
\hline D-Glucose & + & + & - & + & + & + & - \\
\hline Glycerol & + & + & - & - & + & - & - \\
\hline Lysine & - & + & + & + & + & + & - \\
\hline Raffinose & + & + & + & - & - & - & - \\
\hline D-Sorbitol & - & + & + & + & + & - & + \\
\hline Trehalose & - & - & + & + & - & + & + \\
\hline
\end{tabular}


Table 2. DNA G+C contents and DNA-DNA relatedness of strains $H S T 01-2 R^{\top}, \mathrm{HSTO}^{\top}$ and other species of the genus Haloarcula

\begin{tabular}{|c|c|c|c|c|c|c|c|}
\hline \multirow[t]{2}{*}{ Strain } & \multirow{2}{*}{$\begin{array}{c}\text { DNA G }+ \text { C content } \\
(\mathrm{mol} \%)\end{array}$} & \multicolumn{6}{|c|}{ DNA-DNA relatedness (\%) with labelled DNA from: } \\
\hline & & 1 & 2 & 3 & 4 & 5 & 6 \\
\hline 1. HST01-2R $\mathrm{R}^{\mathrm{T}}$ & 61.6 & 100 & 34.0 & 46.9 & 18.8 & 25.5 & 14.0 \\
\hline 2. $\mathrm{HST}_{0} 3^{\mathrm{T}}$ & 62.2 & 32.8 & 100 & 37.9 & 20.7 & 28.0 & 13.4 \\
\hline 3. H. argentinensis JCM $9737^{\mathrm{T}}$ & 62.8 & 36.3 & 41.1 & 100 & 14.3 & 18.5 & 12.7 \\
\hline 4. H. amylolytica JCM $13557^{\mathrm{T}}$ & 61.4 & 34.0 & 29.0 & 54.1 & 100 & 57.2 & 14.9 \\
\hline 5. H. hispanica JCM $8911^{\mathrm{T}}$ & 62.8 & 27.0 & 36.1 & 52.8 & 51.2 & 100 & 11.3 \\
\hline 6. H. vallismortis JCM $8877^{\mathrm{T}}$ & $64.7^{\star}$ & 20.1 & 30.7 & 25.6 & 25.9 & 24.4 & 100 \\
\hline H. marismortui JCM $8966^{\mathrm{T}}$ & $61.8^{\star}$ & 27.8 & 37.3 & 52.0 & 27.9 & 28.3 & 14.5 \\
\hline H. japonica JCM $7785^{\mathrm{T}}$ & $63.3^{*}$ & 39.6 & 42.5 & 32.3 & 23.9 & 25.6 & 15.5 \\
\hline H. quadrata JCM $11048^{\mathrm{T}}$ & $60.1^{*}$ & 24.8 & 38.7 & 39.9 & 21.0 & 28.1 & 28.5 \\
\hline
\end{tabular}

${ }^{\star}$ Data from Oren et al. (1999).

and to the type strains of recognized species of the genus Haloarcula, i.e. Har. argentinensis JCM $9737^{\mathrm{T}}$, Har. amylolytica JCM $13557^{\mathrm{T}}$, Har. hispanica JCM $8911^{\mathrm{T}}$, Har. vallismortis JCM $8877^{\mathrm{T}}$, Har. marismortui JCM $8966^{\mathrm{T}}$, Har. japonica $\mathrm{JCM} 7785^{\mathrm{T}}$ and Har. quadrata JCM $11048^{\mathrm{T}}$ (Wayne et al., 1987), as shown Table 2. In addition, several phenotypic characteristics of strains HST01-2R $\mathrm{R}^{\mathrm{T}}$ and $\mathrm{HST}_{03}{ }^{\mathrm{T}}$, i.e. acid production from raffinose, utilization of sugars and amino acids as energy sources, the $\mathrm{NaCl}$ and $\mathrm{Mg}^{2+}$ ranges for growth and the hydrolysis of tyrosine, clearly distinguished these strains from each other and from recognized species of the genus Haloarcula. Therefore, strains HST01-2 $\mathrm{R}^{\mathrm{T}}$ and $\mathrm{HST}^{\mathrm{T}} \mathrm{3}^{\mathrm{T}}$ represent two novel species in the genus Haloarcula, for which the names Haloarcula salaria sp. nov. and Haloarcula tradensis sp. nov. are proposed, respectively.

\section{Description of Haloarcula salaria sp. nov.}

Haloarcula salaria (sa.la'ri.a. L. fem. adj. salaria of or belonging to salt).

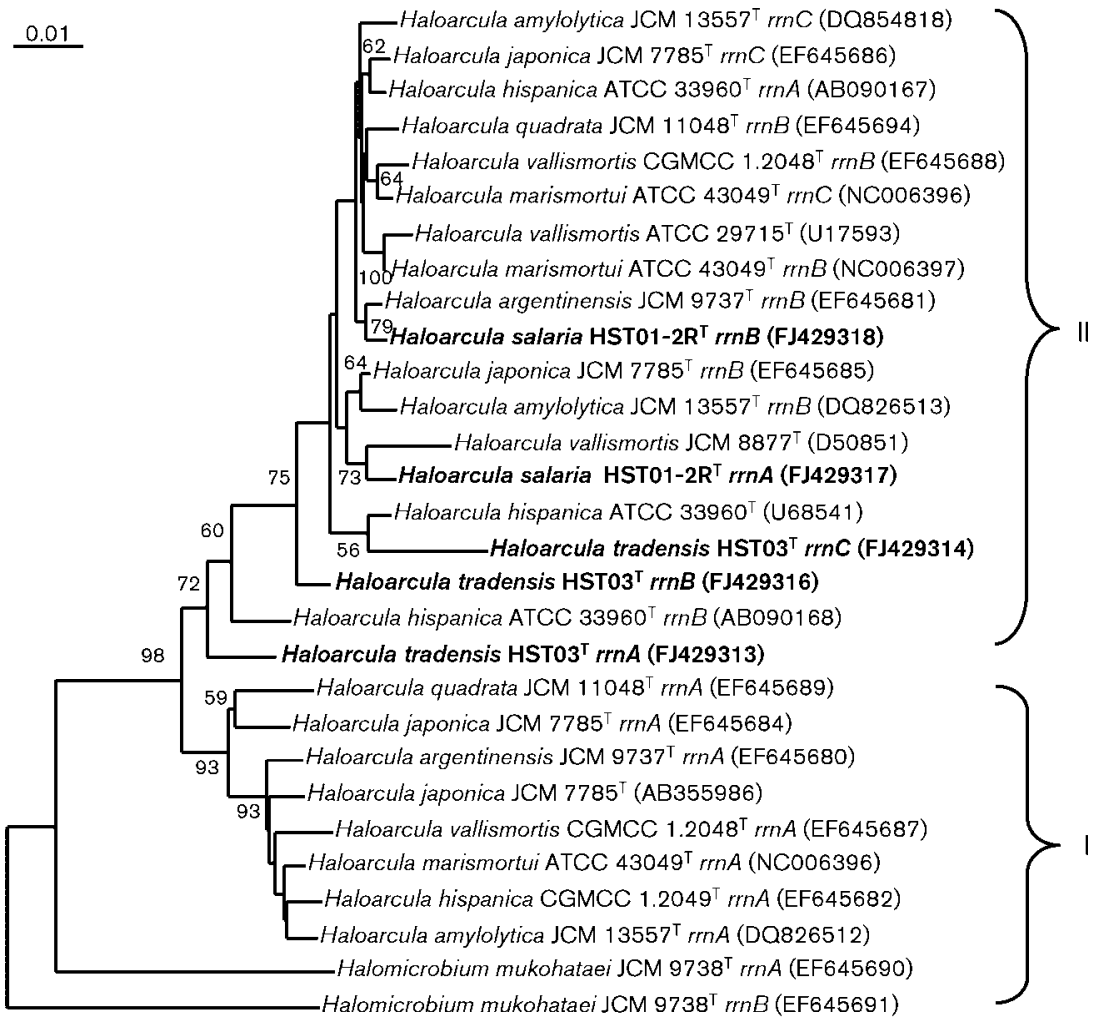

Fig. 2. Phylogenetic tree reconstruction showing the relationships between strains HST01$2 \mathrm{R}^{\top}, \mathrm{HSTO}^{\mathrm{T}}$ and related species of the genus Haloarcula based on 16S rRNA gene sequences. The branching pattern was generated by the neighbour-joining method. Bootstrap percentages $>56 \%$, based on 1000 replications, are shown at the nodes. Bar, 1 substitution per 100 nt positions. 
Cells are Gram-stain negative, non-motile, strictly aerobic pleomorphic rods, $0.6-0.8 \mu \mathrm{m}$ in width and $1.0-2.0 \mu \mathrm{m}$ in length. When grown on a complex medium of neutral $\mathrm{pH}$, colonies are small, entire, translucent and convex $(0.8-$ $2.1 \mathrm{~mm}$ in diameter) after 1 week of incubation at $37{ }^{\circ} \mathrm{C}$ and show red pigmentation. Cells lyse in distilled water. Grows at between 15 and $45{ }^{\circ} \mathrm{C}$ (optimally at $37^{\circ} \mathrm{C}$ ) and at between $\mathrm{pH} 6.0$ and $\mathrm{pH} 8.0$ (optimally $\mathrm{pH}$ 7.0). Grows aerobically but does not grow anaerobically, even in the presence of nitrate. Tests for nitrate reduction, the methyl red/Voges-Proskauer reaction and the formation of indole are negative. Extremely halophilic, requires at least $15 \%$ $(\mathrm{w} / \mathrm{v}) \mathrm{NaCl}$ for growth and the optimal concentration for growth is $20-25 \%(\mathrm{w} / \mathrm{v}) \mathrm{NaCl}$. Growth occurs at $\mathrm{Mg}^{2+}$ concentrations of $2-10 \%(\mathrm{w} / \mathrm{v})$. Catalase and oxidase reactions are positive. Tween 80 and starch are hydrolysed, but skimmed milk, gelatin, tyrosine and xanthine are not hydrolysed. Produces acids from raffinose, but not from cellobiose, glycerol, D-glucose, D-sorbitol, or trehalose. Utilizes cellobiose, glycerol, D-glucose, raffinose, glutamic acid and aspartic acid, but not D-galactose, D-sorbitol, trehalose or lysine as the sole energy source. The type strain is susceptible to bacitracin $(10 \mu \mathrm{g})$, but resistant to chloramphenicol $(30 \mu \mathrm{g})$, tetracycline $(30 \mu \mathrm{g})$, ampicillin $(30 \mu \mathrm{g})$, gentamicin $(30 \mu \mathrm{g})$, rifampicin $(30 \mu \mathrm{g})$, streptomycin $(30 \mu \mathrm{g})$ and novobiocin $(5 \mu \mathrm{g})$. Possesses $\mathrm{C}_{20} \mathrm{C}_{20}$ diether core lipids. MK-8 (91.9\%) and MK-8 $\left(\mathrm{H}_{2}\right)(8.8 \%)$ are present. Possesses PG, PGP-Me, PGS, TGD-2, DGD and two unknown phospholipids.

The type strain, HST01- $2 \mathrm{R}^{\mathrm{T}} \quad\left(=\mathrm{BCC} \quad 40029^{\mathrm{T}}=\mathrm{JCM}\right.$ $15759^{\mathrm{T}}=$ PCU $313^{\mathrm{T}}$ ) was isolated from salt from a sample of fish sauce from Thailand. The DNA G $+C$ content of the type strain is $61.6 \mathrm{~mol} \%$.

\section{Description of Haloarcula tradensis sp. nov.}

Haloarcula tradensis (tra.den'sis. N.L. fem. adj. tradensis of or belonging to Trad, the province in Thailand from where the strain was isolated).

Cells are Gram-stain negative, non-motile, strictly aerobic pleomorphic rods, $0.8-1.2 \mu \mathrm{m}$ in width and $1.0-2.5 \mu \mathrm{m}$ in length. When grown on a complex medium of neutral $\mathrm{pH}$, colonies are small, entire, translucent and convex (0.9$2.3 \mathrm{~mm}$ in diameter) after 1 week of incubation at $37{ }^{\circ} \mathrm{C}$ and show red pigmentation. Cells lyse in distilled water. Grows at between 15 and $45{ }^{\circ} \mathrm{C}$ (optimally at $37^{\circ} \mathrm{C}$ ) and at between $\mathrm{pH} 6.0$ and $\mathrm{pH} 8.0$ (optimally at $\mathrm{pH} 7.0$ ). Grows aerobically, but does not grow anaerobically, even in the presence of nitrate. Tests for nitrate reduction, the methyl red/Voges-Proskauer reaction and the formation of indole are negative. Extremely halophilic, requires at least $15 \%$ $(\mathrm{w} / \mathrm{v}) \mathrm{NaCl}$ for growth and optimal growth occurs at 20 $25 \%(\mathrm{w} / \mathrm{v}) \mathrm{NaCl}$. Growth occurs at $\mathrm{Mg}^{2+}$ concentrations of $2-10 \%(\mathrm{w} / \mathrm{v})$. Catalase and oxidase reactions are positive. Tween 80 and starch (weak reaction) are hydrolysed, but skimmed milk, gelatin, tyrosine and xanthine are not hydrolysed. No acid production from cellobiose, glycerol,
D-glucose, raffinose, D-sorbitol or trehalose. Utilizes cellobiose, glycerol, D-glucose, D-galactose, raffinose, D-sorbitol, glutamic acid, aspartic acid and lysine, but not trehalose as sole energy sources. The type strain is susceptible to bacitracin $(10 \mu \mathrm{g})$ and novobiocin $(5 \mu \mathrm{g})$, but resistant to chloramphenicol $(30 \mu \mathrm{g})$, tetracycline $(30 \mu \mathrm{g})$, ampicillin $(30 \mu \mathrm{g})$, gentamicin $(30 \mu \mathrm{g})$, rifampicin $(30 \mu \mathrm{g})$, streptomycin $(30 \mu \mathrm{g})$ and novobiocin $(5 \mu \mathrm{g})$. Possesses $\mathrm{C}_{20} \mathrm{C}_{20}$ diether core lipids. MK-8 (91.8\%) and MK- $8\left(\mathrm{H}_{2}\right)(8.2 \%)$ are present. Possesses PG, PGP-Me, PGS, TGD-2, DGD and two unknown phospholipids.

The type strain, HST03 ${ }^{\mathrm{T}}\left(=\mathrm{BCC} 40030^{\mathrm{T}}=\mathrm{JCM} 15760^{\mathrm{T}}\right.$ $=$ PCU $314^{\mathrm{T}}$ ) was isolated from salt from a sample of fish sauce in Thailand. The DNA G $+\mathrm{C}$ content of the type strain is $62.2 \mathrm{~mol} \%$.

\section{Acknowledgements}

This study was supported by the Thailand Research Fund as a research grant (2007) for S. N. We thank Dr Sirapan Sukontasing for collecting the fish sauce sample and Miss Susakul Palakawong $\mathrm{Na}$ Ayudthaya for assisting in the use of phase-contrast microscope.

\section{References}

Arahal, D. R., Dewhirst, F. E., Paster, B. J., Volcani, B. E. \& Ventosa, A. (1996). Phylogenetic analyses of some extremely halophilic archaea from Dead Sea water, determined on the basis of their 16S rRNA sequences. Appl Environ Microbiol 62, 3779-3786.

Baliga, N. S., Bonneau, R., Facciotti, M. T., Pan, M., Glusman, G., Deutsch, E. W., Shannon, P., Chiu, Y., Weng, R. S. \& other authors (2004). Genome sequence of Haloarcula marismortui: a halophilic archaeon from the Dead Sea. Genome Res 14, 2221-2234.

Barrow, G. I. \& Feltham, R. K. A. (1993). Cowan and Steel's Manual for the Identification of Medical Bacteria, 3rd edn. Cambridge: Cambridge University Press.

Chaiyanan, S., Chaiyanan, S., Maugel, T., Huq, A., Robb, F. T. \& Colwell, R. R. (1999). Polyphasic taxonomy of a novel Halobacillus, Halobacillus thailandensis sp. nov. isolated from fish sauce. Syst Appl Microbiol 22, 360-365.

Cui, H.-L., Zhou, P.-H. \& Oren, A. (2009). Intraspecific polymorphism of $16 \mathrm{~S}$ rRNA genes in two halophilic archaeal genera, Haloarcula and Halomicrobium. Extremophiles 13, 31-37.

Dussault, H. P. (1955). An improved technique for staining red halophilic bacteria. J Bacteriol 70, 484-485.

Enache, M., Itoh, T., Kamekura, M., Teodosiu, G. \& Dumitru, L. (2007). Haloferax prahovense sp. nov., an extremely halophilic archaeon isolated from a Romanian salt lake. Int J Syst Evol Microbiol 57, 393-397.

Ezaki, T., Hashimoto, Y. \& Yabuuchi, E. (1989). Fluorometric deoxyribonucleic acid-deoxyribonucleic acid hybridization in microdilution wells as an alternative to membrane filter hybridization in which radioisotopes are used to determine genetic relatedness among bacterial strains. Int J Syst Bacteriol 39, 224-229.

Felsenstein, J. (1985). Confidence limits on phylogenies: an approach using the bootstrap. Evolution 39, 783-791.

Gemmell, R. T., McGenity, T. J. \& Grant, W. D. (1998). Use of molecular techniques to investigate possible long-term dormancy of halobacteria in ancient halite deposits. Anc Biomol 2, 125-133. 
Grant, W. D. \& Larsen, H. (1990). Extremely halophilic archaeobacteria. Order Halobacteriales ord. nov. In Bergey's Manual of Systematic Bacteriology, vol. 3, pp. 2216-2219. Edited by J. T. Staley, M. P. Bryant, N. Pfennig \& J. G. Holt. Baltimore: Williams \& Wilkins.

Hezayen, F. F., Tindall, B. J., Steinbüchel, A. \& Rehm, B. H. A. (2002). Characterization of a novel halophilic archaeon, Halobiforma haloterrestris gen. nov., sp. nov., and transfer of Natronobacterium nitratireducens to Halobiforma nitratireducens comb. nov. Int J Syst Evol Microbiol 52, 2271-2280.

Ihara, K., Watanabe, S. \& Tamura, T. (1997). Haloarcula argentinensis sp. nov. and Haloarcula mukohataei sp. nov., two new extremely halophilic archaea collected in Argentina. Int J Syst Bacteriol 47, 7377.

Juez, G., Rodríguez-Valera, F., Ventosa, A. \& Kushner, D. J. (1986). Haloarcula hispanica spec. nov. and Haloferax gibbonsii spec. nov., two new species of extremely halophilic archaebacteria. Syst Appl Microbiol 8, 75-79.

Komagata, K. \& Suzuki, K. (1987). Lipid and cell-wall analysis in bacterial systematics. Methods Microbiol 19, 161-207.

Kumar, S., Tamura, K., Jakobson, I. B. \& Nei, M. (2001). MEGA 2: Molecular evolution analysis software. Bioinformatics 17, 1244-1245.

Leifson, E. (1963). Determination of carbohydrate metabolism of marine bacteria. J Bacteriol 85, 1183-1184.

Lopetcharat, K., Choi, Y. J., Park, J. W. \& Daeschel, M. A. (2001). Fish sauce products and manufacturing: a review. Food Rev Int 17, 65-88.

Minnikin, D. E., O'Donnell, A. G., Goodfellow, M., Alderson, G., Athalye, M., Schaal, A. \& Parlett, J. H. (1984). An integrated procedure for the extraction of bacterial isoprenoid quinones and polar lipids. J Microbiol Methods 2, 233-241.

Namwong, S., Tanasupawat, S., Smitinont, T., Visessanguan, W., Kudo, T. \& Itoh, T. (2005). Isolation of Lentibacillus salicampi strains and Lentibacillus juripiscarius sp. nov. from fish sauce in Thailand. Int J Syst Evol Microbiol 55, 315-320.

Namwong, S., Tanasupawat, S., Visessanguan, W., Kudo, T. \& Itoh, T. (2007). Halococcus thailandensis sp. nov., from fish sauce in Thailand. Int J Syst Evol Microbiol 57, 2199-2203.

Oren, A., Ginzburg, M., Ginzburg, B. Z., Hochstein, L. I. \& Volcani, B. E. (1990). Haloarcula marismortui (Volcani) sp. nov., nom. rev., an extremely halophilic bacterium from the Dead Sea. Int J Syst Bacteriol 40, 209-210.

Oren, A., Ventosa, A. \& Grant, W. D. (1997). Proposed minimal standards for description of new taxa in the order Halobacteriales. Int J Syst Bacteriol 47, 233-238.

Oren, A., Ventosa, A., Gutiérrez, M. C. \& Kamekura, M. (1999). Haloarcula quadrata sp. nov., a square, motile archaeon isolated from a brine pool in Sinai (Egypt). Int J Syst Bacteriol 49, 1149-1155.

Oren, A., Arahal, D. R. \& Ventosa, A. (2009). Emended descriptions of genera of the family Halobacteriaceae. Int J Syst Evol Microbiol 59, 637-642.

Oren, A., Elevi, R., Watanabe, S., Ihara, K. \& Corcelli, A. (2002). Halomicrobium mukohataei gen. nov., comb. nov., and emended description of Halomicrobium mukohataei. Int J Syst Evol Microbiol 52, 1831-1835.

Ross, H. N. M., Collins, M. D., Tindall, B. J. \& Grant, W. D. (1981). A rapid procedure for the detection of archaebacterial lipids in halophilic bacteria. J Gen Microbiol 123, 75-80.
Saito, H. \& Miura, K. I. (1963). Preparation of transforming deoxyribonucleic acid by phenol treatment. Biochim Biophys Acta 72, 619-629.

Saitou, N. \& Nei, M. (1987). The neighbour-joining method: a new method for reconstructing phylogenetic trees. Mol Biol Evol 4, 406-425.

Shao, P., Chen, Y., Zhou, H., Qu, L., Ma, Y., Li, H. \& Jiao, N. (2004). Phylogenetic diversity of Archaea in prawn farm sediment. Mar Biol 146, 133-142.

Stan-Lotter, H., Pfaffenhuemer, M., Legat, A., Busse, H.-J., Radax, C. \& Gruber, C. (2002). Halococcus dombrowskii sp. nov., an archaeal isolate from a Permian alpine salt deposit. Int J Syst Evol Microbiol 52, 1807-1814.

Takashina, T., Hamamoto, T., Otozai, K., Grant, W. D. \& Horikoshi, K. (1990). Haloarcula japonica sp. nov., a new triangular halophilic archaebacterium. Syst Appl Microbiol 13, 177-181.

Takashina, T., Hamamoto, T., Otozai, K., Grant, W. D. \& Horikoshi, K. (1991 ). Haloarcula japonica sp. nov. In Validation of the Publication of New Names and New Combinations Previously Effectively Published Outside the IJSB, List no. 36. Int J Syst Bacteriol 41, 178-179.

Tamaoka, J. \& Komagata, K. (1984). Determination of DNA base composition by reversed-phase high-performance liquid chromatography. FEMS Microbiol Lett 25, 125-128.

Tanasupawat, S., Shida, O., Okada, S. \& Komagata, K. (2000). Lactobacillus acidipiscis sp. nov. and Weissella thailandensis sp. nov., isolated from fermented fish in Thailand. Int J Syst Evol Microbiol 50, 1479-1485.

Tanasupawat, S., Pakdeeto, A., Namwong, S., Thawai, C., Kudo, T. \& Itoh, T. (2006). Lentibacillus halophilus sp. nov., from fish sauce in Thailand. Int J Syst Evol Microbiol 56, 1859-1863.

Tanasupawat, S., Namwong, S., Kudo, T. \& Itoh, T. (2008-2009). Identification of halophilic bacteria from fish sauce (nam-pla) in Thailand. J Culture Collections 6, 69-75.

Tapingkae, W., Tanasupawat, S., Itoh, T., Parkin, K. L., Benjakul, S., Visessanguan, W. \& Valyasevi, R. (2008). Natrinema gari sp. nov., a halophilic archaeon isolated from fish sauce in Thailand. Int J Syst Evol Microbiol 58, 2378-2383.

Thompson, J. D., Gibson, T. J., Plewniak, F., Jeanmougin, F. \& Higgins, D. G. (1997). The CLUSTAL_X windows interface: flexible strategies for multiple sequence alignment aided by quality analysis tools. Nucleic Acids Res 25, 4876-4882.

Thongthai, C., McGenity, T. J., Suntinanalert, P. \& Grant, W. D. (1992). Isolation and characterization of an extremely halophilic archaeobacterium from traditionally fermented Thai fish sauce (nam pla). Lett Appl Microbiol 14, 111-114.

Torreblanca, M., Rodriguez-Valera, F., Juez, G., Ventosa, A., Kamekura, M. \& Kates, M. (1986). Classification of non-alkaliphilic halobacteria based on numerical taxonomy and polar lipid composition, and description of Haloarcula gen. nov. and Haloferax gen. nov. Syst Appl Microbiol 8, 89-99.

Wayne, L. G., Brenner, D. J., Colwell, R. R., Grimont, P. A. D., Kandler, O., Krichevsky, M. I., Moore, L. H., Moore, W. E. C., Murray, R. G. E. \& other authors (1987). International Committee on Systematic Bacteriology. Report of the ad hoc committee on reconciliation of approaches to bacterial systematics. Int J Syst Bacteriol 37, 463-464.

Yang, Y., Cui, H. L., Zhou, P. J. \& Liu, S. J. (2007). Haloarcula amylolytica sp. nov., an extremely halophilic archaeon isolated from Aibi salt lake in Xin-Jiang, China. Int J Syst Evol Microbiol 57, 103-106. 